\title{
Increase in Tolerance towards Violence against Women in the Private Sphere: Changes in Slovenian Public Opinion between 2005 and 2012
}

\author{
Mateja SEDMAK, Ana KRALJ \\ University of Primorska, Science and Research Centre, Koper, Slovenia \\ mateja.sedmak@zrs.upr.si,ana.kralj@zrs.upr.si
}

\begin{abstract}
The aim of this article is to present Slovenian public opinion on questions related to violence against women in the private sphere. The article sheds light on the results of two surveys carried out in 2005 and 2012 among the citizens of the Republic of Slovenia, and places special emphasis on differences that appeared in the interval between their deliveries. When presenting Slovenian public opinion on violence against women in Slovenia, the article focuses on the levels of sensitivity to violence and social tolerance towards violence, the assessment of knowledge of the phenomenon, its visibility, the perception of violence against women as a private or public issue and, above all, the connection between traditional values (related to the perception of female and male gender roles and the position of women and men in society) and tolerance towards violence. The analysis reveals a downward trend in sensitivity to violence and an upward trend in tolerance to violence against women and apportioning blame to victims, as well as a growing perception of domestic violence as a private and not public issue.
\end{abstract}

Key words: violence against women, private sphere, public opinion, Slovenia

\section{Introduction}

The majority of contemporary surveys on violence against women in the private sphere reveal that violence is closely linked to inequality and unequal power relations between the genders in society. Such a finding is also highlighted by the 2006 United Nations report, according to which it is the unequal power relations and the ensuing discrimination against women that form the basis for violence against women (United Nations, 2006). Such a view brings to the fore the structural nature of violence 
and avoids the simplified ascription of violence against women to personal traits and individual or family psychopathology. Violence against women therefore depends primarily on social evaluation of the genders and gender roles; from the point of view of feminist theory, it is mostly dependent on the existence of the still omnipresent patriarchal model of social organization facilitating the domination of men over women in different cultures throughout history. Social tolerance towards domestic violence, which is a concomitant phenomenon, is a reflection of patriarchal norms that support male dominance in the family (Yllö, 1993; Jogan, 2001).

If social subordination of women offers the broader explanatory context of violence against women, the afore-mentioned UN international study (United Nations, 2006) points out the following narrower explanatory factors: (1) legitimized use of violence in conflict situations and (2) hegemonic doctrines of privacy, especially all legal doctrines of the protection of privacy, home and family that are used as an excuse for inactivity or inadequate activity of the state and its policies in the field of violence in the private sphere. The international study also lists a third explanatory factor, (3) inadequate activity or even inactivity of the state and its institutions in general, as a result of which the responsibility for dealing with violence against women is taken by NGOs and other civil and social groups that have considerably less power and often also less competence in comparison with state-run institutions. It is only at the end of the list that one finds (4) individualized factors related to behavioural patterns in the family, which public opinion (!) usually perceives as the most important, thus ignoring or minimizing more important causes of violence. Yet one also needs to acknowledge the fact that the individual or family factors are so inextricably intertwined with the structural ones that it is impossible to draw a clear boundary between them. When speaking of the former, we have in mind the following risk factors: socio-economic status, individual history of violence exposure, family or individual behavioural patterns, etc.

The position of women in society and social (in)equality in terms of gender are therefore the two key points to observe when addressing violence against women. What about the situation in Slovenia? Published annually by the United Nations, the Gender Equity Index ${ }^{1}$ analyzed the

\footnotetext{
${ }^{1}$ Accessible at: http://www.socialwatch.org/node/499.
} 
position of women in 2012 in 154 countries all over the world, including Slovenia. The index was calculated on the basis of the analysis of the gap between women and men in terms of possibilities, accessibility and participation in the fields of education, economic activity and political power. When gender equality was assessed (all the afore-mentioned three criteria were taken into account), Slovenia ranked slightly above the European average, thus being almost at the same level as its neighbouring countries (Croatia, Italy, Hungary, Austria), yet far below the top countries boasting the highest rate of gender equality (Norway, Finland, Iceland, Sweden, Denmark, New Zealand). It should also be pointed out that Slovenia ranked highest (i.e. as very good) when the field of education was put under the microscope, while economic participation was assessed as low and political participation or empowerment of women as very low.

Even if violence against women or, if speaking in broader terms, domestic violence is a serious social issue with negative consequences at different levels, Slovenia witnesses a problematic absence of empirical studies, on the basis of which the experts, politics and NGOs could conceive the guidelines for their operation and introduce preventive measures. Similar lack of empirical research has also been reported in other geographical environments (Worden and Carlson, 2005a, 2005b). Despite their scarcity (for Slovenia, see: Sedmak et al., 2006; Eurobarometer, 2010; Filipčič, 2011), the empirical studies are of high importance as they provide a good insight into the changing attitude to the violencerelated questions such as how people perceive violence, what is the level of tolerance towards violence in the private sphere, and how the perceptions of violence and tolerance towards it change through time. If early studies (mostly by Anglo-Saxon authors) have focused on physical violence, today's public opinion perceives violence in much broader terms and shows the awareness of and sensitivity to less explicit forms of violence (e.g. psychological or economic violence), too. Judging by opinion polls, one can argue that, in general, both Europe and the USA have witnessed a decrease in tolerance towards violence, that people are more aware of psychological forms of violence and that they will more likely disapprove of occasional acts of violence and abuse (Klein et al., 1997; Johnson and Sigler, 2000). Interestingly, Johnnson and Sigler also point out the possibility of over-estimating the occurrence of violence in 
the private sphere, which they perceive as a result of more widespread public debate about domestic violence and increased social sensitivity to the issue. Having taken into consideration the last three polls conducted in Alabama in 1987, 1992 and 1997, they ascertained that the respondents claimed that violence was present in every second intimate relationship, which was a much higher rate than the one reported by government and non-government organizations dealing with violence in the USA (Johnson and Sigler, 2000). A similar effect on public opinion, which over-estimated the occurrence of domestic violence as a result of better dissemination of information on the issue, was also reported by Stalans, whose survey highlighted the public belief according to which as many as $67 \%$ of male partners in the USA were violent towards their wives or female partners, which was a considerably higher rate than the one officially reported (Stalans, 1996, in Worden and Carlson, 2005a: 1199).

Public opinion looms large, much larger than a superficial observer would think. Efficient organization of campaigns launched by the civil society, support for referenda, support for election candidates, prevention of amendments to the legislation, concrete interventions in physical space or in activities undertaken by individuals or institutions, etc., are viable only when public opinion has been sufficiently unified, formulated and expressed. Unfortunately, public opinion can also be manipulated, distorted and falsified in order to make it serve partial (political) interests. In the case of violence against women and domestic violence, public opinion is of key importance, since increased public sensibility to the issue of domestic violence raises public awareness of its existence and, consequently, lowers public tolerance towards it, encourages the victims of violence to stand up to the bullies, and stigmatizes the perpetrator instead of putting the blame on the victim.

Last but not least, people's points of view and public opinion on the occurrence of violence against women as well as the conceptualization of its causes and other characteristics matter as they reflect the general perception of the issue in society. Moreover, they can be important from the point of view of policy implementation since policy effectiveness may depend on the fact of to what extent people's points of view are taken into account, and to what extent mainstream opinion perceives them as "its own" and acceptable (Worden and Carlson, 2005b: 1220). At the end of the day, public opinion (transmitted via family, relatives, friends, neighbours and others) 
also affects the response of victims, aggressors and potential aggressors (Worden and Carlson, 2005b). ${ }^{2}$

The aim of this article is therefore to present Slovenian public opinion on questions related to violence against women in the private sphere. The article sheds light on the results of two surveys carried out in 2005 and 2012 among the citizens of the Republic of Slovenia, and places special emphasis on differences that appeared in the interval between their deliveries. In both cases, the representative samples included adult citizens of the Republic of Slovenia, with the first survey being conducted in June 2005 within the comprehensive project entitled Analysis of Domestic Violence in Slovenia - Proposals for Preventive Actions and Measures. ${ }^{3}$ Its objective was a thorough analysis of the existing situation and the general social climate of opinion on questions related to domestic violence in Slovenia. For the purpose of the present article, we selected several questions from the 2005 survey and included them in the second survey, which was carried out in September 2012.

When presenting Slovenian public opinion on violence against women in Slovenia, the article will be interested in the levels of sensitivity to violence and social tolerance towards violence, the assessment of knowledge of the phenomenon, its visibility, the perception of violence against women as a private or public issue, and above all the connection between traditional values and tolerance towards violence.

When discussing gender equality and violence against women, one should not ignore the current economic, social and value-related crisis sweeping across the old continent, including Slovenia. History has shown

\footnotetext{
${ }^{2}$ To summarize a few concrete findings on the importance and impact of public opinion: (1) The support for new legislation on violence in the private sphere depends on public support for it and on firm belief in the incontestable culpability of the aggressor as someone who perceives the causes of violence in the perpetrator's insanity or addiction may find the criminalization of the aggressive partner an inappropriate measure; (2) the individual's beliefs on what are the causes of violence have an impact on his/her evaluation of his/her own experiences, behaviour and choices. A woman victim will less likely search for help or legal protection (or advise it to others) if public opinion and/or her belief claims that a certain level of violence is normal and excusable and that women are responsible for managing their partner's behaviour; (3) the efficiency of state intervention in the form of preventive and intervention programmes depends on the existing set of beliefs held by the public and its susceptibility to new information (Worden and Carlson, 2005b).

${ }^{3}$ The target research project financed by the Slovenian Ministry of Labour, Family and Social Affairs was conducted by the Science and Research Centre of the University of Primorska from 2004 to 2006.
} 
that a socio-economic crisis goes hand in hand with attempts at (and actual) restoration of traditional values, as well as considerable aggravation of the economic and social situation of the most vulnerable groups (children, people with disabilities, women, migrants, etc.) and the spread of different types of extremist phenomena. It is no exaggeration to claim that Slovenia is witnessing not only the disintegration of (the last remnants) of the welfare state, economy, minimal political culture and basic norms of civilization, but also the accelerated slide of a large part of the population to the verge of the subsistence level. As a result, it is feared that the consequences of the existing social trend will start to manifest themselves in the fields of gender equality and domestic violence.

\section{Methodology and data collection}

The subsequent presented results reflect the findings of the two surveys conducted in 2005 and 2012, with sample sizes of 1006 and 314 respectively. Our population consisted of adult residents of Slovenia. With the phonebook as the sampling frame, we used simple random sampling to ensure the generalizability of the research findings. Despite the gap between the sample sizes, they being of 1006 and 314 respondents, we can still draw valuable conclusions, as the findings of the sample sizes of 250 respondents or more do not differ greatly, thus allowing comparison of the research data. Additionally, we have analysed the data using the basic statistical overview of the data from 2005 and 2012 surveys respectively and afterwards conducted bivariate analysis of association of the researched questions according to gender, age, religious background as well as previous experience with domestic violence. For determination of the association between variables, we have used the Cramer V measure where we adopted conventional criteria on significance value at 0.05 or lower. Such significance would point to association among variables and the relationship among them not affiliated to chance.

The 2005 survey saw the participation of 699 women (69.5\%) and 307 men (30.5\%), while the 2012 survey involved 212 women $(67.5 \%)$ and 102 men $(32.5 \%)$. Given the fact that the sample shares of men and women involved in both surveys do not match the actual population shares of men and women in the Republic of Slovenia, the interpreted answers have been weighted in terms of gender in accordance with statistical rules in order to make the sample representative. 
The respondents were divided into six age groups (18-28, 29-39, 40-50, 51-61, 62-72 and 73 and more). The two surveys differ in the following nuances related to the respondents' age structure: the 2005 survey involved considerably more young people aged 18-28, as well as 29-39, and less people older than 62 years in comparison with the 2012 survey (see Table 1).

In terms of education, the largest group of participants in both surveys had completed secondary or vocational school. It was followed by the group of respondents with completed faculty or college, then by those with completed primary school, then by participants with uncompleted primary school and, finally, by those with completed Master's or $\mathrm{PhD}$ studies (see Table 1).

The surveys paid special attention to the relation of traditional values (related to the perception of female and male gender roles and the position of women and men in society) on the perception of violence against women. For that reason, they were also interested in the respondents' religion, with Catholics being the largest group in both surveys, followed by non-believers and adherents of other religions (see Table 1).

Table 1. The demographic data of 2005 and 2012 research

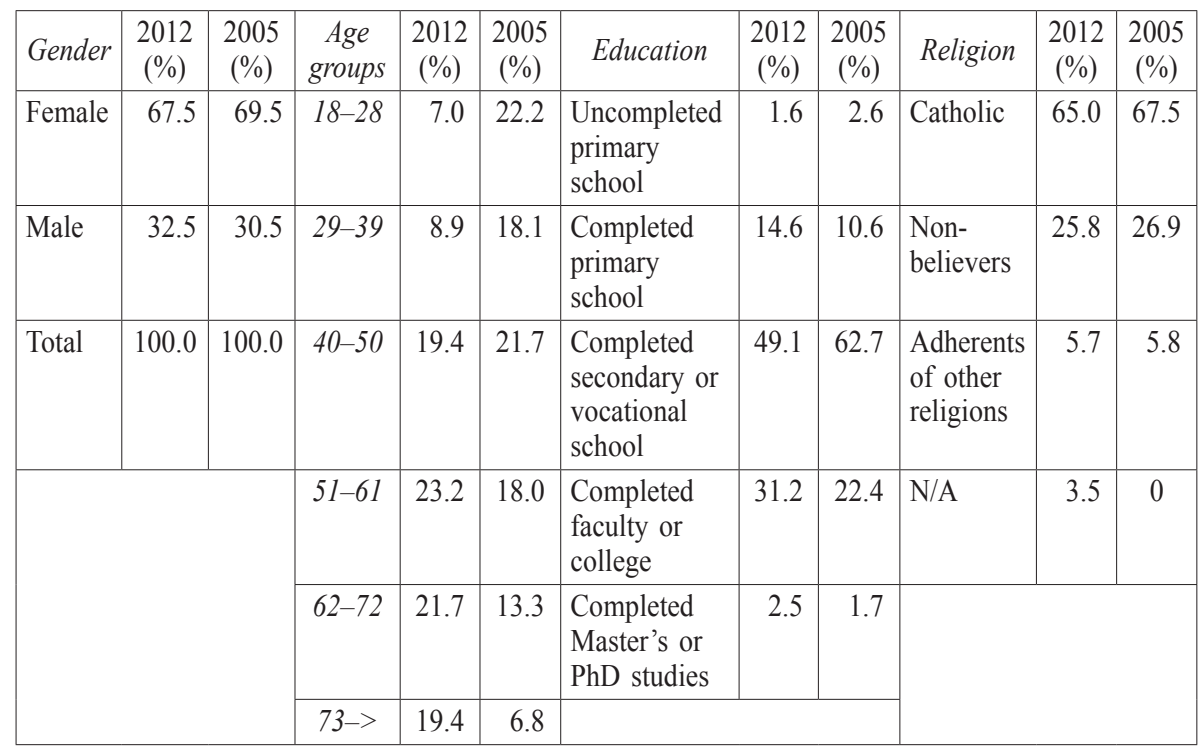

\section{Attitudes to violence against women in Slovenia}

The 2005 survey examined the respondents' attitudes to violence against women and, to put it in broader terms, domestic violence. Its aim was 
to ascertain the level of sensitivity and tolerance to violence or, in other words, what the respondents regarded as violence. It also enquired about the subjective opinion on the dissemination of information on the phenomenon and the visibility/invisibility of violence in the private sphere. In order to obtain those answers, it measured the level of agreement or disagreement with the following statements:

1. Sometimes it is the wife's fault that her husband has hit her.

2. A slap in the wife's face is not a sign of domestic violence.

3. Under no circumstances, does the husband have the right to hit his wife and vice versa.

4. If the wife or husband forbids his/her partner to be in touch with his/her family, s/he imposes a major restriction on him/her.

5. Partner bullying is not a sign of domestic violence.

6. If a wife or husband hits her/his partner because $s /$ he is jealous, that is a sign of true love.

7. Domestic violence is still hidden within four walls.

8. Informing people on domestic violence helps to reduce violence.

9. There is general lack of information where to turn for help if you experience violence in the family.

The occurrence of violence is closely linked to the general social climate that can be more or less tolerant of different manifestations of violence. Societies with zero tolerance towards domestic violence and towards violence in general can actually expect to record low levels of domestic violence and violence against women, and vice versa. Having declared independence in 1991, Slovenia needed a relatively long period to address the issue of domestic violence and violence against women. It was only in March 1999 that the Criminal Code (more precisely, Article 299) defined domestic violence as a criminal offence. In 2008, the parliament passed the Family Violence Prevention Act (hereinafter: FVPA), whose importance was not only symbolic (the Act integrates regulations previously incorporated into various acts) but also systemic, as the Act addressed domestic violence in a more systemic, integrated manner (Zakon o preprečevanju nasilja v družini [FVPA], 2008).

The general social climate and the attitudes to domestic violence/violence against women in Slovenia in 2012 and 2005 can be inferred from the Table 2 . 


\begin{tabular}{|c|c|c|c|c|c|c|c|c|c|c|c|}
\hline \multirow{4}{*}{ 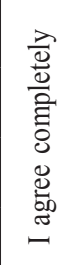 } & \multirow{2}{*}{ §ิ) } & $\partial^{\circ}$ & $\stackrel{0}{0}$ & $a$ & No & 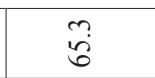 & $\stackrel{?}{*}$ & ?్̧ & $\begin{array}{l}n \\
\stackrel{\infty}{+}\end{array}$ & $\overrightarrow{\widetilde{n}}$ & ì \\
\hline & & $\omega$ & in & a & $\hat{6}$ & if & $\stackrel{F}{F}$ & $\bar{\sigma}$ & $\stackrel{\infty}{\underset{\gamma}{\sigma}}$ & 이 & $\vec{\sim}$ \\
\hline & \multirow{2}{*}{$\stackrel{\overbrace{}}{\stackrel{\sim}{\Xi}}$} & $a^{\circ}$ & $\stackrel{\circ}{r}$ & $\stackrel{\circ}{+}$ & $\begin{array}{l}0 \\
\text { in }\end{array}$ & 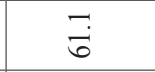 & $m$ & $\stackrel{\infty}{m}$ & $\begin{array}{l}\infty \\
\stackrel{m}{m}\end{array}$ & $\stackrel{+}{\grave{j}}$ & $\vec{a}$ \\
\hline & & 4 & $=$ & $\simeq$ & $\stackrel{\infty}{ }$ & 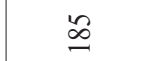 & 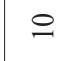 & $=$ & 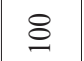 & 8ิ & $\stackrel{\infty}{\sim}$ \\
\hline \multirow{4}{*}{ 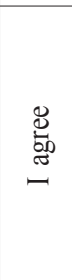 } & \multirow{2}{*}{ ஜे } & $\partial^{\circ}$ & $\overrightarrow{\mathrm{I}}$ & $\stackrel{g}{ \pm}$ & శֶ & $\stackrel{n}{\sim}$ & ț & $\underbrace{\infty}_{0}$ & $\begin{array}{l}\dot{0} \\
\ddot{n}\end{array}$ & $\stackrel{\circ}{m}$ & $\vec{a}$ \\
\hline & & $\leftarrow$ & 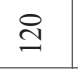 & I & $\vec{b}$ & $\stackrel{\sim}{\sim}$ & ช్ & 8 & $\bar{n}$ & $\vec{m}$ & $\underset{\sim}{+\infty}$ \\
\hline & \multirow{2}{*}{$\stackrel{\sim}{\check{\sim}}$} & $\partial^{\circ}$ & $\stackrel{n}{\tilde{n}}$ & $\begin{array}{l}\infty \\
\infty \\
\infty\end{array}$ & $\frac{m}{m}$ & ले & $\vec{r}$ & $\stackrel{6}{=}$ & $\begin{array}{l}0 \\
\tilde{n}\end{array}$ & $\hat{q}$ & $\frac{n}{n}$ \\
\hline & & 4 & $\sqrt{6}$ & $i n$ & à & $\S$ & $\vec{\sim}$ & $m$ & $\underset{t}{t}$ & I & $\Xi$ \\
\hline \multirow{4}{*}{ 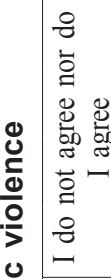 } & \multirow{2}{*}{ 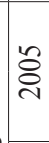 } & $a^{\circ}$ & 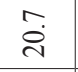 & $\stackrel{n}{ \pm}$ & $\hat{b}$ & in & స̃. & $\stackrel{\circ}{\underset{ \pm}{ \pm}}$ & $\tilde{a}$ & $\hat{\vec{\lambda}}$ & $\stackrel{\sim}{\sim}$ \\
\hline & & 4 & ષ્ત & I & 8 & $\stackrel{\infty}{n}$ & \& & $\stackrel{\mathscr{D}}{\simeq}$ & 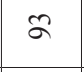 & 라 & $\stackrel{\infty}{\circ}$ \\
\hline & \multirow{2}{*}{$\stackrel{ }{\stackrel{\sim}{\sim}}$} & $0^{\circ}$ & $\stackrel{m}{i}$ & $\tilde{a}$ & $\stackrel{b}{i}$ & $\stackrel{\circ}{i}$ & in & $\stackrel{?}{\varrho}$ & $\vec{\sigma}_{0}^{\circ}$ & $\stackrel{n}{\simeq}$ & $\stackrel{+}{0}$ \\
\hline & & 4 & 3 & Әे & I & 0 & $=$ & $\bar{m}$ & 고 & $\bar{n}$ & లె \\
\hline \multirow{4}{*}{ 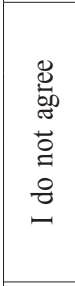 } & \multirow{2}{*}{ 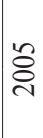 } & $0^{\circ}$ & $\vec{\infty}$ & ¿n & $\stackrel{b}{\dot{m}}$ & $\stackrel{\sim}{m}$ & & $\stackrel{0}{\infty}$ & 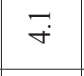 & $\begin{array}{l}\infty \\
\infty\end{array}$ & $\begin{array}{l}n \\
n\end{array}$ \\
\hline & & 4 & $\infty$ & 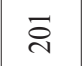 & r & $\bar{m}$ & $\nexists$ & $\stackrel{ \pm}{I}$ & $\vec{\gamma}$ & $\infty$ & $\approx$ \\
\hline & \multirow{2}{*}{$\stackrel{\stackrel{\sim}{\sim}}{\stackrel{\sim}{2}}$} & $a^{\circ}$ & $\stackrel{\text { iे }}{\circ}$ & $\ddot{n}$ & $\stackrel{+}{i}$ & $\stackrel{\circ}{\circ}$ & 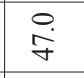 & $\stackrel{m}{m}$ & $n$ & $\exists$ & $\begin{array}{l}0 \\
\dot{n} \\
\end{array}$ \\
\hline & & 4 & $\widetilde{\sigma}$ & $\hat{0}$ & $\infty$ & $a$ & ભે & \& & I & $m$ & 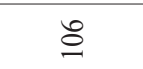 \\
\hline \multirow{4}{*}{ 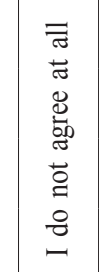 } & \multirow{2}{*}{ ஓें } & $0^{\circ}$ & $\stackrel{n}{\tilde{y}}$ & $\hat{\dot{q}}$ & min & $\underset{\forall}{\digamma}$ & in & 㝘 & $\stackrel{+}{i}$ & $\stackrel{+}{+}$ & $\ddot{\infty}$ \\
\hline & & 4 & $\stackrel{\vartheta}{\ni}$ & के & ก & $F$ & $\stackrel{\mathcal{F}}{n}$ & กี & $\stackrel{\nabla}{\Delta}$ & $\stackrel{F}{F}$ & $\infty$ \\
\hline & \multirow{2}{*}{ 굴 } & $a^{\circ}$ & $\begin{array}{l}\overrightarrow{0} \\
\stackrel{m}{m}\end{array}$ & $\frac{a}{m}$ & $\vec{m}$ & $\stackrel{\circ}{-}$ & $\dot{n}$ & $\stackrel{\circ}{\stackrel{\vec{\gamma}}{ }}$ & Э & $\stackrel{m}{m}$ & $\stackrel{9}{r}$ \\
\hline & & 4 & $\stackrel{\varrho}{=}$ & 우 & $\stackrel{0}{ }$ & $n$ & $\stackrel{8}{ }$ & 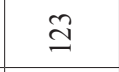 & in & 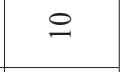 & $\stackrel{\sim}{\sim}$ \\
\hline & & & 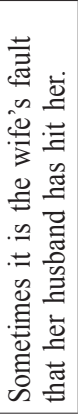 & 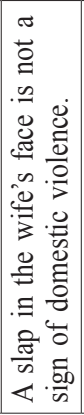 & 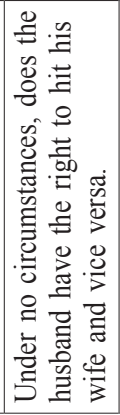 & 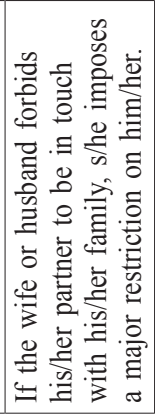 & 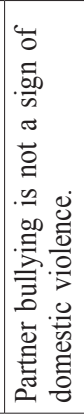 & 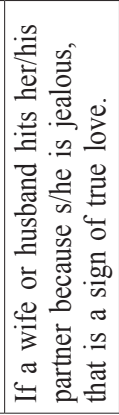 & 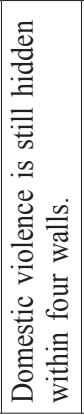 & 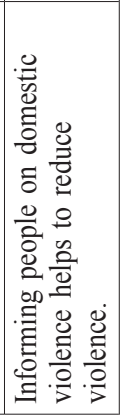 & 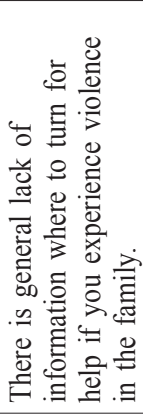 \\
\hline
\end{tabular}


Table 2 reveals the changes in the attitudes to domestic violence that happened between 2012 and 2005. Even if the answers related to the first five statements, which measure the level of tolerance towards violence, are similar in both surveys, there are important differences between those obtained in 2012 and those obtained seven years before that. Even if the majority of respondents did not agree at all in 2012 with the statements that relativize domestic violence, it can be observed that the percentages in question decreased in comparison with those of 2005. In general, one can therefore detect the trend toward lower sensitivity to different forms of violence and, consequently, the trend toward higher level of tolerance toward behaviour characterized as violent.

In 2012, the statement "Sometimes it is the wife's fault that her husband has hit her" recorded the following answers: $35.6 \%$ of respondents did not agree with it at all and $20 \%$ did not agree with it. In 2005, the percentage of respondents who did not agree with it at all was higher, i.e. 42.5. The statement also recorded an important difference in the percentage of people who agreed with it: in 2005, the percentage amounted to 12.1, while in 2012 it increased to 20.5, which is not insignificant. By contrast, the percentage of those who agreed with it completely was slightly higher in 2005 than in 2012 , yet it was low in both cases (6\% and $3.6 \%$ respectively).

In the past, victims of violence were often blamed for the act of violence perpetrated against them, in particular when it came to sexual violence: according to Amir, for example, it is the victim who draws attention to herself and sparks the interaction between her and the aggressor, with her behaviour usually triggering off potential acts of violence (Bergen, 1998, in Medarić, 2011: 38). Even if the engagement of (especially feminist) theorists has shifted the attention from the victim, who has been held responsible for violence, to the aggressor, such perceptions are still present (as corroborated by the answers in our surveys). Worden and Carlson (2005b: 1222) point out three aspects of putting the blame on the victim: according to the first, which is presented above, the women triggers (and implicitly deserves) ${ }^{4}$ a violent response owing to her behaviour; the second perceives the woman as a masochist who enjoys the violent behaviour and, consequently, encourages it; the third blames the victim for staying in a violent relationship.

\footnotetext{
${ }^{4}$ The authors also reveal that the above-mentioned argument was considered legitimate in court a few generations ago.
} 
Similar answers were obtained in relation to the statement "A slap in the wife's face is not a sign of domestic violence". In 2005, the percentage of those who did not agree with it at all was higher than in 2012 (40.7\% vs. $31.9 \%$ respectively). Concomitantly, in 2005, the percentage of respondents who did not agree was lower (14.9\% vs. 18.8\%), while the percentage of those who agreed completely was higher (9.5\% in 2005 vs. $4 \%$ in 2012).

The statement "Under no circumstances, does the husband have the right to hit his wife, and vice versa" was mostly met with agreement or even total agreement both in 2012 and 2005, with the percentage of people who agreed completely being higher in 2005 (68.2\% vs. 57.6\%). A similar trend was observed in the case of the statement "If the wife or husband forbids his/her partner to be in touch with his/her family, s/he imposes a major restriction on him/her", with the percentage of those who agreed completely again being higher in 2005 than in 2012 (65.3\% vs. 61.1\%).

A similar trend was recorded when the respondents expressed their opinion as regards the statements "Partner bullying is not a sign of domestic violence" and "If a wife or husband hits her/his partner because s/he is jealous, that is a sign of true love". Both in 2012 and 2005, the majority of them did not agree with both of them (at all). Yet the percentage of those who did not agree at all was higher in 2005 than in 2012. A significant difference between the two time periods was also observed in the percentage of respondents who agreed with the latter; in 2012 it increased to 11.6, while in 2005 it amounted to 6.8 .

If the first four statements were used in order to establish the level of sensibility to violence and what the respondents perceived as violence, the next four statements were used in order to examine another dimension of domestic violence: the subjective evaluation of the presence of violence, the dissemination of information on the phenomenon and its visibility/invisibility. Both in 2012 and 2005, the majority of respondents agreed that "Domestic violence is still hidden within four walls", yet in 2005 there were more participants who agreed with the statement completely $(48.5 \%$ vs. $32.8 \%$ ). Similarly, both surveys revealed that respondents (completely) agreed with the statement that the dissemination of information on violence helps to reduce violence; again, more respondents agreed completely in 2005 than in 2012 (32.1\% vs. 23.4\% respectively); yet the 2005 survey revealed a considerably higher percentage of the undecided $(21.7 \%$ ticked the option "I do not agree nor do I agree"). In 2005, considerably more 
people agreed completely that there was lack of information on where to turn for help in case of domestic violence $(25.7 \%$ vs. $9.1 \%)$. A relatively high percentage of the sample agreed with the statement both in 2005 and $2012(29.1 \%$ and $37.5 \%$ respectively).

And how do the respondents' answers differ as regards their gender, education, age or religion?

When their answers do reveal differences related to the above-mentioned parameters, the differences show that it is usually men, respondents with lower education, the elderly and the believers who tend to relativize and minimalize violence and to ascribe culpability to the victims of violence.

To provide just a few examples: both surveys show that the agreement with the statement "Sometimes it is the wife's fault that her husband has hit her" increases with age and lower levels of education. Catholics agree with it more often than non-believers, and in 2005 there were even a small percentage of women who approved of it. Similarly, both in 2012 and 2005 the agreement with the statement "A slap in the wife's face is not a sign of domestic violence" increases with lower levels of education; in 2005, the statement won less approval by women and non-believers than by men and believers respectively. In 2012, it was again more often the respondents with higher education who totally agreed with the statement "Under no circumstances, does the husband have the right to hit his wife, and vice versa", while in 2005 it was the women and non-believers. In both surveys, the statement "If the wife or husband forbids his/her partner to be in touch with his/her family, s/he imposes a major restriction on him/her" won higher approval from respondents with higher education and non-believers than by those with lower education and believers respectively; in 2005, such an opinion was more often held by younger age groups than the older ones. Similar trends could be observed in the case of other statements.

Naturally, it would be completely incorrect to conclude from the above-mentioned trends that the perpetrators are mostly older men with lower education who believe in God. Several studies have pointed out that higher education is not a "safeguard" against violence; people with higher education may be just defter at covering up their acts of violence. According to a survey done by Filipčič (2011), the majority of perpetrators of acts of violence had completed secondary school, while the percentages of those with lower or higher levels of education were almost the same. The data 
collected suggest that, in principle, men, believers, the elderly and people with lower education are more prone to relativize violence and to hold the victims culpable for the aggressor's behaviour; in other words, they are prone to have more traditional and patriarchal views of violence against women (which can have serious social consequences).

There are a number of other studies that testify to the existence of gender-related differences as regards the views of and attitudes to domestic violence. In general, women not only perceive violence in broader terms according to which psychic violence and movement restriction are also forms of violence, but also regard individual acts of violence much more seriously than men and are less willing to exculpate domestic violence. It has to be pointed out, however, that (at least) the studies carried out in the US cultural context do not record a clear and unambiguous correlation between the attitude to violence on the one hand and ethnicity, age and socio-economic status on the other (Gentemann /1984/, Greenblat /1985/, Kristiansen and Giulietti /1990/, Yick and Agbayani-Siewert /1997/, Wagner and Mongan /1998/, Miller and Bukva /2001/, in Worden and Carlson, 2005a: 1199-1200). When interpreting their public opinion survey, Miller and Bukva (in Worden and Carlson, 2005a: 1215) emphasize that variations in public opinion cannot be ascribed to stereotypes related to gender, social status, education or generation.

\section{Social tolerance towards violence against women in the private sphere}

Violence should not be addressed as a personal problem of the individual exposed to it since its occurrence partly depends on the response of society. Society may condemn and penalize it, and thus aspire to decrease the possibility of its occurrence, or tolerate, minimalize or even normalize it as something that simply happens and cannot be avoided in personal relationships.

Contemporary literature in the fields of social studies pays considerable attention to the question of when a certain social phenomenon becomes a social issue (Horsfall, 2012: 3-6). A social issue definitely goes beyond personal opinions on what is problematic and what not, since it has social dimensions and affects many people. In addition, people need to recognize a social issue as such, which means that it needs to be felt by many people to such an extent that they feel the need for a change and are ready to 
do something to enact it. The recognition of a social issue by a sufficient number of people to constitute a "critical mass", however, can be a long process. If people are tormented by something that they do not recognize as a social issue, then it does not exist as such. Their suffering becomes a social issue only when they reach an agreement that "something is wrong" and are ready to organize themselves in order to deal with it. Before such recognition happens, it does not mean that people do not suffer; they do, yet their suffering has yet to become part of social awareness. Though tormented by something, people do not necessarily recognize their situation as a social issue. They often understand their suffering as a personal or moral shortcoming, lack of competence or virtue, bad luck, their own fault, etc. Even if they realize that they are facing a collective phenomenon, they may interpret it fatalistically as their destiny, the "nature of things" or something that is far beyond their power to enact change.

From the point of view of social tolerance towards violence, the answers to the question on what types of behaviour the respondents regard as violent proved to be quite interesting and telling. In 2012, the majority of respondents labelled threats, verbal humiliation and bullying as acts of violence (with the percentages amounting to $84.5 \%, 91.6 \%$ and $93.3 \%$ respectively). Surprisingly, a high percentage of respondents believed that a slap was not an act of violence (44.2\%), and $7.7 \%$ of respondents claimed that forced sexual intercourse was not a case of violence either. Statistically significant association of gender and the actions perceived as violence revealed that more women than men perceived a slap $\left(\chi^{2}=9.97, \mathrm{~V}=0.19\right.$, sig. $=0.00)$, threats $\left(\chi^{2}=7.26, \mathrm{~V}=0.16\right.$, sig. $\left.=0.01\right)$ and forced sexual intercourse $\left(\chi^{2}=4.67, \mathrm{~V}=0.12\right.$, sig. $\left.=0.03\right)$ as acts of violence.

When the invasion of the partner's privacy was put under the microscope, the boundary between what was perceived as violent behaviour and what not proved to be more blurred. In 2012, 51.0\% of respondents did not find checking the partner's pockets problematic, and $33.1 \%$ did not regard opening the partner's letters as an invasion of the partner's privacy and personal integrity. Such attitudes can be interpreted either as a sign of a high level of trust and intimacy in an intimate relationship or as a sign of relatively low awareness and respect of personal freedom and autonomy. A similar attitude was recorded in the case of the control over the partner's financial means: according to $44.4 \%$ of respondents, that was not an instance of violence. Statistically significant association 
was established in terms of the respondents' age show where, by contrast to other age groups, younger respondents did not perceive letter opening $\left(\chi^{2}=10.77, \mathrm{~V}=0.19\right.$, sig. $\left.=0.01\right)$ as an act of violence. Meanwhile association was also confirmed between the respondents' level of education (if we now turn to another factor) and labelling letter opening $\left(\chi^{2}=\right.$ 20.61, $\mathrm{V}=0.27$, sig. $=0.00)$ and financial control over partner $\left(\chi^{2}=8.07\right.$, $\mathrm{V}=0.17$, sig. $=0.02$ ) as violent acts, which was more common among respondents with higher education. We believe the difference is deserving of special attention. Why are younger respondents more tolerant of the invasion of privacy and personal autonomy? Perhaps the answer lies in the fact that younger people understand privacy differently than older generations, whose boundaries between personal and private life on the one hand and public life on the other have reportedly been much clearer. The last decade witnessed a drastic change in the relation between private and public life, largely owing to the influence of mass media and popular culture and the development of information and communication technologies, as a result of which the boundaries between the two spheres of life have become thoroughly blurred and much more permeable. The huge popularity of a multitude of talk shows and reality shows (with high ratings in Slovenia, too) in which the participants' intimacy is exposed to the public on the one hand, and the boom of social networks where people voluntarily disclose their private lives to a very wide circle of people on the other, must have led to the fact that people, in particular younger people, no longer perceive other forms of invasion of privacy, such as letter opening, checking the partner's text messages, etc., unacceptable or even problematic. If our hypothesis is corroborated in the long run and the symptom we have detected turns into a trend, then we will have to open an in-depth discussion not only on the confusion between what is private and what public, but also whether a strict differentiation between the private and the public, which the classical liberal theory (Sennett, 2002 [1977]) perceived as a prerequisite for democratic life, is still a relevant social issue or not.

If we ignore this slight, yet most probably significant difference, the comparison of data from the 2012 survey with that from 2005 revealed no essential changes in the respondents' attitudes to violence (see Table 3); the percentages mostly differed by one or two percentage points. Slightly bigger differences were detected only when the respondents had to evalu- 
ate whether a slap and control over the partner's financial means were an act of violence. In the case of the former, the percentage of those who believed so decreased by $7.8 \%$ in 2012 , and in the case of the latter by $6.3 \%$.

Table 3. Attitudes to the violent nature of individual types of behaviour

\begin{tabular}{|l|c|c|}
\hline \multirow{2}{*}{\multicolumn{1}{|c|}{ Is an act of violence also: }} & \multicolumn{2}{c|}{ Yes (\%) } \\
\cline { 2 - 3 } & 2005 & 2012 \\
\hline A slap & 63.6 & 55.8 \\
\hline Checking the partner's pockets & 49.3 & 49.0 \\
\hline A threat & 83.0 & 84.5 \\
\hline Verbal humiliation & 87.4 & 91.6 \\
\hline Opening the partner's letters & 67.9 & 66.9 \\
\hline Control over the partner's financial means & 61.9 & 55.6 \\
\hline Forced sexual intercourse & 92.4 & 92.3 \\
\hline Bullying & 93.1 & 93.3 \\
\hline
\end{tabular}

\section{Violence against women - a private problem of the family or a public issue?}

In Slovenia, violence against women is no longer a personal problem as it acquired wider social dimensions when the state recognized the need systematically to regulate the prevention of violence against women in the domestic sphere and intimate relationships. Violence against women is a social issue also because of its consequences, as it helps to perpetuate unequal power relations between the genders. If women strive to survive in a violent relationship and to ensure their own safety, they cannot put their efforts into education, public engagement and other spheres of their lives. In addition, violence against women places a large financial burden on the state (costs of treatment, costs related to absence from work, costs related to further violence prevention...). The sooner domestic violence is perceived as part of the public sphere and the more people regarding it as illegitimate and unacceptable, the more pressing issue it becomes, not because its occurrence might have increased, but because it has been recognized as a public issue. As a result, there is an increase in possibilities of its prevention and mitigation of its consequences.

A relatively high percentage of respondents $(41.4 \%)$ who believed in 2012 that domestic violence was a private problem of the family (while 
$58.8 \%$ perceived it as a wider public issue) is therefore not only a surprising but also alarming fact. Statistically significant association $\left(\chi^{2}=\right.$ $7.78, \mathrm{~V}=0.16$, sig. $=0.02)$ as regards the respondents' education structure revealed that the percentage of respondents who were of opinion that domestic violence was a public issue increased with the respondents' level of education. Thus, more than half of respondents $(53.5 \%)$ with completed primary school answered that domestic violence was a private problem of the family, while more than two thirds of respondents $(69.5 \%)$ with completed higher education believed it was a public issue. Another factor influencing the decision whether to place the issue within the private or public sphere was religion: respondents who defined themselves as Catholics were more prone to regard it as a private problem of the family than adherents of other religions and non-believers. Such a view was held by $46.1 \%$ of respondents who defined themselves as Catholics, while the percentage was considerably lower in other categories, amounting to $33.3 \%$ and $34.6 \%$ in the case of adherents of other religions and non-believers respectively.

Another alarming result is obtained if one compares the results of the 2012 survey with those of the 2005 survey (see Table 4): the percentage of respondents who believed that domestic violence was a private matter of the family increased by $8.7 \%$ (in 2005 , it amounted to $32.7 \%$ of respondents, while in 2012 it rose to $41.1 \%$ ).

Table 4. Domestic violence as a private or public issue

\begin{tabular}{|l|c|c|}
\hline & $2005(\%)$ & $2012(\%)$ \\
\hline A private problem of the family & 32.7 & 41.4 \\
\hline A public issue & 67.3 & 58.6 \\
\hline
\end{tabular}

The data show that Slovenia has recently witnessed a unique contradiction: on the one hand, the recognition of violence as a public issue by the media and the state sub-systems has increased, which is reflected in numerous serious discussions on violence published or broadcast by the mass media and in a better defined and stricter legislation. On the other, the country has seen a decrease in people's recognition of violence as a public issue. The differences between 2005 and 2012 may not be dramatic, yet they do reveal changes pointing towards a direction with which Slovenia cannot be satisfied. 


\section{Myths about family life, devotion to traditional values and attitudes to violence}

People hold different views on how the true or ideal family should look; as pointed out by several female authors (Švab, 2001; Rener et al., 2006; Medarić, 2011; Jogan, 2013), many of them have been influenced by myths or illusory notions. According to the most frequent, persistent and widespread myth, "family is the basic cell of society" and "the natural atom of society". This "basic cell" has clear coordinates: a two-parent family based on marriage, with heterosexual parents complementing one another: the mother takes cares of the house and the children, while the father adds a touch of strictness to the upbringing and provides for the family materially. Such doctrinal and organicist understanding of family and society does not allow for divorce. According to a second myth, "family is the micro cosmos of society"; family is society in miniature, its mirror, the saviour of society in crisis, the custodian of basic common, social and national values; therefore there "should be nothing wrong" in families. In case there is, then one should conceal it. A third myth claims that family is a "sanctuary" in a heartless world, a safe haven where one can retreat from the sorrows and perils of the external world. Naturally, families often function as havens and therapeutic environments, yet the myth can be dangerous because it simply assumes that social antagonism can be done away with on the doorstep of one's home, as well as because it overemphasizes and idealizes one aspect of family life and completely ignores other, less romanticized aspects of daily life in families. Unrealistic, idealized and mythologized images of one's family can form the background of many family tragedies in which many extreme forms of domestic violence culminate, when it is revealed that reality can be completely different from what we persistently foster in our collective imaginary worlds. According to the traditional views, family is first and foremost a place of trust and safety, while the occurrence of violence in families contradicts such notions. As Pascall (1997: 45) puts it: "But violence at home contradicts both sociological and commonplace stereotypes of family life: home is a place of safety and trust, the family is the focus of love and affection; the family is a unit with common interests, even where members have different roles. But violence in families indicates that for many women home is not a place of safety, that it is the centre of intense human emotions of all kinds - including anger and hatred as well 
as love, that the interests of different family members do not inevitably coincide and that men in families assert power over women."

Stereotypical notions of the relation between the genders, gender roles and intimate relationships are (at least) partially reproduced in public situations. What such views lack is the understanding of violence in families (and against women) as a structural problem related to gender inequality. Our surveys therefore wanted to examine to what extent the general public holds views that support patriarchal organization of family and wider social order, thus indirectly or directly influencing to some extent the perception of domestic violence and violence against women. Both surveys asked the respondents to express their level of (dis)agreement with the following statements:

1. Housekeeping is better suited to women.

2. Intellectual work is better suited to men.

3. It is well worth getting a slap or two in order to keep the family together.

In $2012,17 \%$ of respondents (completely) agreed with the statement "Housekeeping is better suited to women" (Table 5), 16.7\% were undecided, while $66.2 \%$ did not agree (at all). Statistically significant $\left(\chi^{2}=\right.$ $19.73, \mathrm{~V}=0.25$, sig. $=0.01)$ association revealed an important connection between the respondents' (dis)agreement with the statement and their education. The lower the level of completed education, the higher the level of agreement with the statement: more than one third of respondents (36.1\%) with completed primary school thus (completely) agreed with it, while the percentage of respondents who had completed college or faculty education amounted to $11.5 \%$. The traditional view according to which the woman's place is in the kitchen is more often held by the believers than non-believers: it won (total) approval by $18.8 \%$ of Catholics, $23.8 \%$ of adherents of other religions and $12.2 \%$ of non-believers.

Table 5. Dis/agreement with the statement "Housekeeping is better suited to women"

\begin{tabular}{|l|r|r|r|r|}
\hline \multirow{2}{*}{} & \multicolumn{2}{|c|}{2012} & \multicolumn{2}{c|}{2005} \\
\cline { 2 - 5 } & $\mathrm{f}$ & \multicolumn{1}{c|}{$\%$} & $\mathrm{f}$ & \multicolumn{1}{c|}{$\%$} \\
\hline I do not agree at all & 114 & 36.6 & 325 & 33.5 \\
\hline I do not agree & 92 & 29.6 & 181 & 18.6 \\
\hline I do not agree nor do I agree & 52 & 16.7 & 223 & 22.9 \\
\hline I agree & 35 & 11.4 & 156 & 16.1 \\
\hline I agree completely & 17 & 5.6 & 86 & 8.9 \\
\hline Total & 311 & 100.0 & 971 & 100.0 \\
\hline
\end{tabular}


The comparison with results from the 2005 survey revealed that the percentage of respondents who did not agree with the statement (at all) was lower in 2005, when it amounted to $52.1 \%$, while in 2012 it amounted to $66.2 \%$.

The statement "Intellectual work is better suited to men" (Table 6) won (complete) approval by $14.5 \%$ respondents, $9.4 \%$ were undecided, while $76.1 \%$ did not agree with it (at all). Statistically significant association $\left(\chi^{2}\right.$ $=14.08, \mathrm{~V}=0.22$, sig. $=0.01)$ related to gender show that there were more women than men who (completely) opposed the statement $(83.6 \% \mathrm{vs}$. $69.3 \%$ respectively). A higher level of agreement was recorded in the oldest respondents (older than 72 years) and in those with lower levels of education (the statement won /complete/ approval by $30.3 \%$ respondents with completed primary school, $17.1 \%$ of respondents with completed secondary school and $3.8 \%$ of respondents with completed college or faculty). When it comes to religion, the non-believers agreed with it to a considerably lesser extent than the believers: the percentage of Catholics who agreed with it (completely) amounted to $17.4 \%$, the percentage of adherents of other religions to $31.8 \%$ and the percentage of non-believers to $4.9 \%$.

The comparison with the results of the previous survey showed similar results: in 2005, 75.1\% of respondents did not agree with it (at all), with the percentage of those who did not agree at all having decreased by several percentage points (in 2005, it amounted to $56.0 \%$, in 2012 it fell to $48.3 \%$ ).

Table 6. Dis/agreement with the statement "Intellectual work is better suited to men"

\begin{tabular}{|l|r|r|c|c|}
\hline \multirow{2}{*}{} & \multicolumn{2}{|c|}{2012} & \multicolumn{2}{c|}{2005} \\
\cline { 2 - 5 } & $\mathrm{f}$ & $\%$ & $\mathrm{f}$ & $\%$ \\
\hline I do not agree at all & 148 & 48.3 & 539 & 56.0 \\
\hline I do not agree & 85 & 27.8 & 183 & 19.1 \\
\hline $\begin{array}{l}\text { I do not agree nor do } \\
\text { I agree }\end{array}$ & 29 & 9.4 & 132 & 13.7 \\
\hline I agree & 39 & 12.5 & 68 & 7.1 \\
\hline I agree completely & 6 & 2.0 & 40 & 4.1 \\
\hline Total & 307 & 100.0 & 962 & 100.0 \\
\hline
\end{tabular}

The statement "It is well worth getting a slap or two in order to keep the family together" (Table 7) won (complete) approval by $27.1 \%$ of respondents, $15.1 \%$ were undecided, while $57.7 \%$ did not agree with 
it (at all). Statistically significant association $\left(\chi^{2}=33.35, \mathrm{~V}=0.33\right.$, sig. $=0.00)$ points to an age-sensitive link revealing that younger respondents (aged 18-39) agreed with it to a much lesser extent (9.8\%) than older respondents, with the percentage of the middle-aged and older generations amounting to $23.9 \%$ and $38.7 \%$ respectively. Association of attitudes and the respondents' religion points to the percentage of believers (completely) agreeing with it being considerably higher than that of non-believers: it amounted to $32.8 \%$ in Catholics, to $42.1 \%$ in adherents of other religions and to $11.3 \%$ in non-believers $\left(\chi^{2}=22.57, \mathrm{~V}=0.28\right.$, sig. $\left.=0.00\right)$.

The comparison with the results of the 2005 survey reveals that the percentage of respondents agreeing with the statement increased by almost one tenth $(8.7 \%)$, while that of the undecided remained almost the same.

Table 7. Dis/agreement with the statement "It is well worth getting a slap or two in order to keep the family together"

\begin{tabular}{|l|r|r|r|r|}
\hline \multirow{2}{*}{} & \multicolumn{2}{|c|}{2012} & \multicolumn{2}{c|}{2005} \\
\cline { 2 - 5 } & $\mathrm{f}$ & \multicolumn{1}{c|}{$\%$} & $\mathrm{f}$ & \multicolumn{1}{c|}{$\%$} \\
\hline I do not agree at all & 109 & 36.1 & 416 & 43.2 \\
\hline I do not agree & 65 & 21.6 & 213 & 22.2 \\
\hline I do not agree nor do I agree & 45 & 15.1 & 156 & 16.2 \\
\hline I agree & 68 & 22.6 & 118 & 12.3 \\
\hline I agree completely & 14 & 4.5 & 59 & 6.1 \\
\hline Total & 300 & 100.0 & 962 & 100.0 \\
\hline
\end{tabular}

The comparison of results of the percentages of respondents who (completely) agree with abovementioned statements regarding traditional perceptions of gender roles reveals that the percentage of respondents (completely) agreeing with the statement on housekeeping being better suited to women decreased by $8.0 \%$ in 2012 , while in the other two cases the share of respondents (completely) agreeing with the statements increased by 3.3 and $8.7 \%$ (Table 8 ).

Table 8. Agreement with statements regarding traditional perceptions of gender roles (\% of respondents who /completely/ agree)

\begin{tabular}{|l|c|c|c|}
\hline & 2005 & 2012 & $\Delta \%$ \\
\hline Housekeeping is better suited to women. & 25.0 & 17.0 & -8.0 \\
\hline Intellectual work is better suited to men. & 11.2 & 14.5 & 3.3 \\
\hline $\begin{array}{l}\text { It is well worth getting a slap or two in } \\
\text { order to keep the family together. }\end{array}$ & 18.4 & 27.1 & 8.7 \\
\hline
\end{tabular}


We were also interested in the respondents' attitudes to divorce, which the traditional view of family as "the basic cell of society" often considers to be an irresponsible or at least risky step to take. In 2012, divorce was (completely) accepted by $57.9 \%$ of respondents, $22.0 \%$ were undecided, while $20.0 \%$ did not approve of it (at all). The comparison of results with those from 2005 revealed that the attitude to divorce did not change drastically, since the percentages of people who opposed it, were undecided or approved of it remained more or less the same. Statistically significant association related to the respondents' educational structure $\left(\chi^{2}=33.00, \mathrm{~V}\right.$ $=0.33$, sig. $=0.00)$ indicate that the percentage of respondents who did not approve of it (at all) was considerably lower in the case of those with completed college or faculty (9.9\%) if compared with those with completed secondary school $(25.0 \%)$ and primary school $(26.6 \%)$. The attitude to divorce also depends on religion: Catholics did not approve of it (at all) in the case of $27.2 \%$ of respondents, while the percentage was lower in adherents of other religions and non-believers, i.e. $15.0 \%$ and only $6.3 \%$ respectively. The comparison also revealed that the percentage of respondents who did not approve of divorce (at all) was considerably higher among those who believed that violence was a private problem of the family $(32.2 \%)$ than among those who perceived it as a wider social issue (12.7\%).

The 2005 survey also examined whether there were correlations between the devotion to traditional values and perceptions of domestic violence. The following attitudes or statements were selected as the indicators of "devotion to traditional values", which could also be termed conservatism: (1) disapproval of divorce, (2) the belief that housekeeping is better suited to women, (3) the belief that intellectual work is better suited to men and (4) the belief that it is well worth getting a slap or two in order to keep the family together. The respondents who did not approve of divorce (at all) and at the same time (completely) agreed with the last three statements were characterized as "traditional", those who (completely) approved of divorce and did not agree with the statements (at all) as "liberal", and those who held neither a very positive nor a very negative attitude to the statements as "undecided". Judging by the indicators of "devotion to traditional values", we established that $10.9 \%$ of respondents classified as "traditionalists", $49.7 \%$ as "liberals", and $40.2 \%$ as the "undecided". The same indicators were applied when processing the results of the 2012 survey, revealing that the percentage of "traditionalists" stayed almost the 
same, amounting to $8.7 \%$, while major changes were related to the percentages of "undecided" and "liberal" respondents, with the former decreasing by more than a tenth to $29.8 \%$, and the latter increasing by more than a tenth to $61.5 \%$.

In 2005, the respondents whom we classified as "traditionalists" proved to be more tolerant of different forms of violence, be it either direct physical violence (such as a slap or forced sexual intercourse) or indirect violence (such as the invasion of partner's privacy). Thus, two thirds of "traditionalists" believed that a slap was not a sign of violence by contrast to three quarters of "liberals" who perceived it as an act of violence. Forced sexual intercourse was regarded as an act of violence by $97.8 \%$ of "liberal" and $75 \%$ of "traditional" respondents. Letter opening was considered as violence by three quarters of "liberals" and only a half of "traditionalists", with an even bigger difference in opinion being recorded in the case of financial control over the partner's means, which was labelled as an act of violence by two thirds of "liberals" and only a third of "traditionalists". The latter were also more prone to apportion blame to the victim (they were more prone to agree with the statement that "Sometimes it is the wife's fault that her husband has hit her") and to justify or to relativize certain acts of violence (they were more prone to agree with the statements that hitting your partner because you were jealous was a sign of true love and that a slap in the partner's face was not a sign of domestic violence). ${ }^{5}$

The results of the 2012 survey (Table 9) indicated that in comparison with "liberals" "traditionalists" were less likely to assess that domestic violence was a (very) common phenomenon in Slovenia, which was substantiated by Cramer's measure of association $\left(\chi^{2}=21.83, \mathrm{~V}=0.27\right.$, sig. $\left.=0.01\right)$; whereas such an association was not revealed by the 2005 survey.

On the other hand, the 2012 survey did not show significant differences in the evaluation of the (non)violent nature of individual types of behaviour, with the exception of the statement that partner bullying was not a case of domestic violence, which won (complete) approval by almost a third (30.8\%) of "traditional" and only $8.8 \%$ of "liberal" respondents. Similarly, the 2012 survey showed differences in opinion as regards the question on whether women themselves can sometimes be blamed for violence inflicted on them: as many as $47.2 \%$ of "traditional" respond-

\footnotetext{
${ }_{5}$ The correlations between the variables are descriptive in nature; they were obtained through bivariate analysis and consequently do not reflect (simple) causality.
} 
ents (completely) agreed with the statement, while such view was held by only $14.2 \%$ of "liberal" respondents. The 2012 survey again confirmed the "traditionalists" tendency to relativize acts of violence: the statement that a slap was not a sign of domestic violence won (complete) approval by $65.4 \%$ of "traditional" and only " $16.1 \%$ " of "liberal" respondents. Similarly, a third of the former (62.9\%) and only $7.6 \%$ of the latter believed that hitting your partner because of jealousy was a sign of true love. The belief that violence was completely unacceptable in an intimate relationship was held by $90.6 \%$ of "liberals" and by $70.3 \%$ of "traditionalists" (while $14.8 \%$ of "traditionalists" and $5.2 \%$ of "liberals" did not agree /at all/ with the statement that under no condition did the husband or wife have the right to hit his/her partner).

Table 9. Agreement with the statement regarding prevalence of domestic violence in Slovenia (2012)

\begin{tabular}{|c|c|c|c|c|c|c|}
\hline & & & Traditionalists & Undecided & Liberals & Total \\
\hline \multirow{10}{*}{$\begin{array}{l}\text { Domestic } \\
\text { violence } \\
\text { in } \\
\text { Slovenia }\end{array}$} & \multirow{2}{*}{$\begin{array}{l}\text { Very common } \\
\text { phenomenon }\end{array}$} & Count & 5 & 16 & 48 & 69 \\
\hline & & $\%$ & 18.5 & 17.6 & 25.8 & 22.7 \\
\hline & \multirow{2}{*}{$\begin{array}{l}\text { Common } \\
\text { phenomenon }\end{array}$} & Count & 10 & 40 & 87 & 137 \\
\hline & & $\%$ & 37.0 & 44.0 & 46.8 & 45.1 \\
\hline & \multirow{2}{*}{$\begin{array}{l}\text { Neither common, } \\
\text { nor non-common }\end{array}$} & Count & 10 & 11 & 30 & 51 \\
\hline & & $\%$ & 37.0 & 12.1 & 16.1 & 16.8 \\
\hline & \multirow{2}{*}{$\begin{array}{l}\text { It is not common } \\
\text { phenomenon }\end{array}$} & Count & 2 & 23 & 21 & 46 \\
\hline & & $\%$ & 7.4 & 25.3 & 11.3 & 15.1 \\
\hline & \multirow{2}{*}{$\begin{array}{l}\text { Absolutely } \\
\text { non- common } \\
\text { phenomenon }\end{array}$} & Count & 0 & 1 & 0 & 1 \\
\hline & & $\%$ & .0 & 1.1 & .0 & .3 \\
\hline \multicolumn{2}{|l|}{ Total } & Count & 27 & 91 & 186 & 304 \\
\hline
\end{tabular}

The correlation between political conservatism and the tendency to hold the victims of violence culpable (e.g. "sometimes it is the woman's fault because she has provoked the perpetrator") was pointed out already by a study published in 1990 by Kristiansen and Giulietti (1990); a similar hypothesis on the correlation between "traditional views" largely held by older generations and apportioning blame to victims who "behaved provocatively" was pointed out by Worden and Carlson (2005a). Even more telling results were revealed by the 2010 European study (Eurobarometer, 2010 ) according to which $52 \%$ of respondents claimed that violence was caused by "women's provocative behaviour". In Slovenia, the percentage of 
respondents holding such views was even more alarming, amounting to as many as $79 \%$, thus being far above the European average. We believe that such results should give rise to a serious discussion not only in Slovenia but also in the wider European area.

\section{Conclusion}

What do the changes in public opinion (on violence against women and in the private sphere) that happened between 2005 and 2012 tell us and what does Slovenian public opinion tell us? To recapitulate: the analysis has revealed a downward trend in sensitivity to violence and an upward trend in tolerance to violence against women and apportioning blame to victims, as well as a growing perception of domestic violence as a private and not a social issue. Even if not drastic, the changes did happen and are slightly alarming. ${ }^{6}$ Alarming because the Family Violence Prevention Act adopted in 2008 has not yielded the envisaged outcomes, because Slovenia has not yet launched systemic programmes on prevention of and/or education on violence against women/in the private sphere, because we can realistically expect that in the time of a general socio-economic crisis the insensitivity to violence against women/in the private sphere will grow, because Slovenia does not keep a central statistical record on the prevalence of the phenomenon $^{7}$ and because we still live in a society permeated by traditional and patriarchal views of men and women. Our surveys show that at least at the level of attitudes men are still prone to relativize violence and minimalize its impact. Uncritical glorification of family and marriage based on "natural" division of gender roles may not only dangerously relativize violence against women in a domestic environment, but also veil all the possibilities for carrying out acts of violence. In the context of domestic violence recognition and prevention, the traditional notions of family as a safe haven and an untouchable nest are not only dangerous but also a platform for perpetuating violence, whether we like this fact or not. The aim of this elaboration is not to demonize family and family life; the fact

\footnotetext{
${ }^{6}$ At this stage, some additional caution in interpretation is needed. The results revealing the increase of tolerance toward domestic violence could also be partially influenced by the fact that the sample of respondents from 2012 is to some extent older than the sample from 2005. And older respondents are usually committed to more traditional values.

${ }^{7}$ It should be pointed out that Slovenia is one of the rare EU member states that has no publicly accessible database on the prevalence of violence against women (European Institute for Gender Equality, 2013).
} 
is that (according to public opinion polls) family is still the most important environment for reproducing intimacy and a "safe haven" to the majority of people, yet one should also not ignore the fact that families as well as other spheres of daily life can be a platform for the manifestation and reproduction of power relations at work in society.

The results of our public opinion surveys show that the findings by Černič Istenič and Kneževič (2003) are still valid and that Slovenia has not achieved a major breakthrough in the last decade in the field of attitudes and values related to violence against women and domestic violence. A decade ago, the afore-mentioned female authors assessed that "the Slovenian value system and behaviour are characterized by concealed tolerance towards violence" (Černič Istenič and Kneževič, 2003: 133). A decade later, we could add only that public discourse on violence against women and violence in the private sphere may have intensified, yet led to no real decrease in tolerance towards violence; by contrast, judging by our second public opinion survey, one can conclude that Slovenia has been witnessing a new increase in tolerance towards acts of violence committed in the private sphere.

In the time of general promotion of democratic principles of modern societies, we tend to forget that violence against women does not concern some other, remote and allegedly "undeveloped" countries in terms of economy and culture (it suffices to think of the images of covered Muslim women so often propagated by the media). Moreover, violence against women is not an individual or personal issue; on the contrary, it is an instance of violation of basic human rights. Only when the phenomenon is recognized as such and, consequently, appropriately penalized - not only formally ${ }^{8}$ but also informally, i.e. through open public disapproval and condemnation, which means through a change in public opinion - only then can violence be expected to decline in real life.

\section{REFERENCES}

Černič Istenič, Majda and Kneževič, Duška (eds) (2003). Nasilje nad ženskami ali kako doseči ničelno toleranco: analiza strokovnih, znanstvenih in statističnih podatkov o nasilju nad ženskami v družini za Slovenijo v obdobju od 1998 do 2003 (Poročilo raziskave). Ljubljana: Inštitut za medicinske vede, ZRC SAZU.

\footnotetext{
${ }^{8}$ Needless to say, formal recognition is a prerequisite for the recognition at all other levels.
} 
Eurobarometer (2010). Domestic Violence against Women: Report. Special Eurobarometer 344, September 2010, http://ec.europa.eu/public_opinion/archives/ ebs/ebs_344_en.pdf.

European Institute for Gender Equality (2013). Review of the implementation of the Beijing Platform for Action in the EU Member States: Violence against women - Victim support (Main findings). Luxembourg: Publications Office of the European Union.

Filipčič, Katja (2011). Pojavnost nasilja in odzivnost na nasilje v zasebni sferi in partnerskih odnosih (Študija). Ljubljana: Inštitut za kriminologijo pri Pravni fakulteti v Ljubljani.

Horsfall, Sara Towe (2012). Social Problems: An Advocate Group Approach. Boulder: Westview Press.

Jogan, Maca (2001). Seksizem v vsakdanjem življenju. Ljubljana: Fakulteta za družbene vede.

Jogan, Maca (2013). “Družbena (ne)enakost spolov v slovenski postsocialistični zavesti”, Teorija in praksa, 50 (1): 5-38.

Johnson, Ida M. and Sigler, Robert T. (2000). "Public perceptions: The stability of the public's endorsements of the definition and criminalization of the abuse of women", Journal of Criminal Justice, 28 (3): 165-179. doi: 10.1016/S00472352(00)00033-7

Klein, Ethel, Campbell, Jacquelyn, Soler, Esta and Ghez, Marissa (1997). Ending Domestic Violence: Changing Public Perceptions/Halting the Epidemic. Thousand Oaks: Sage Publications.

Kristiansen, Connie M. and Giulietti, Rita (1990). "Perceptions of Wife Abuse: Effects of Gender, Attitudes toward Woman, and Just-World Beliefs among College Students", Psychology of Women Quarterly, 14 (2): 177-189. doi: 10.1111/j.1471-6402.1990.tb00013.x

Medarić, Zorana (2011). "Domestic Violence against Women in Slovenia: A Public Problem?", Revija za socijalnu politiku, 18 (1): 25-45. doi: 10.3935/rsp.v18i1.947

Pascall, Gillian (1997). Social Policy: A New Feminist Analysis [2nd ed.]. London and New York: Routledge.

Rener, Tanja, Sedmak, Mateja, Švab, Alenka and Urek, Mojca (2006). Družine in družinsko življenje v Sloveniji. Koper: Univerza na Primorskem, Znanstvenoraziskovalno središče, Založba Annales.

Sedmak, Mateja, Kralj, Ana, Medarič, Zorana and Simčič, Blaž (2006). Nasilje $v$ družinah v Sloveniji: rezultati raziskave. Koper: Univerza na Primorskem, Znanstveno-raziskovalno središče.

Sennett, Richard (2002 [1977]). The Fall of Public Man. London and NewYork: Penguin Books.

Švab, Alenka (2001). Družina: od modernosti k postmodernosti. Ljubljana: Znanstveno in publicistično središče.

United Nations (2006). In-depth study on all forms of violence against women. Report of the Secretary-General, July 2006, http://www.un.org/ga/search/view doc.asp?symbol=A/61/122/Add. 
Worden, Alissa Pollitz and Carlson, Bonnie E. (2005a). "Attitudes and Beliefs about Domestic Violence: Results of a Public Opinion Survey, I. Definitions of Domestic Violence, Criminal Domestic Violence, and Prevalence", Journal of Interpersonal Violence, 20 (10): 1197-1218. doi: 10.1177/0886260505278530

Worden, Alissa Pollitz and Carlson, Bonnie E. (2005b). "Attitudes and Beliefs about Domestic Violence: Results of a Public Opinion Survey, II. Beliefs about Causes", Journal of Interpersonal Violence, 20 (10): 1219-1243. doi: $10.1177 / 0886260505278531$

Yllö, Kersti A. (1993). "Through a Feminist Lens: Gender, Power and Violence”, in: Richard J. Gelles and Donileen R. Loseke (eds). Current Controversies on Family Violence. London: Sage Publications, pp. 47-62.

Zakon o preprečevanju nasilja v družini [FVPA] (2008). Uradni list RS, št. 16/2008, http://www.uradni-list.si/1/objava.jsp?urlid=200816\&stevilka=487.

\title{
Povećanje tolerancije prema nasilju nad ženama u privatnoj sferi: promjene u slovenskom javnom mnijenju između 2005. i 2012. godine
}

\author{
Mateja SEDMAK, Ana KRALJ \\ Sveučilište Primorska, Znanstveno-istraživački centar, Koper, Slovenija \\ mateja.sedmak@zrs.upr.si,ana.kralj@zrs.upr.si
}

\begin{abstract}
Cilj je ovoga rada predstaviti slovensko javno mnijenje o pitanjima koja se odnose na nasilje nad ženama u privatnoj sferi. Članak predstavlja rezultate dvaju istraživanja provedenih 2005. i 2012. godine među građanima Republike Slovenije, te stavlja poseban naglasak na razlike koje su se pojavile u intervalu između njihovih provođenja. Prilikom predstavljanja slovenskoga javnog mnijenja o nasilju nad ženama u Sloveniji članak se usredotočuje na razinu osjetljivosti na nasilje i društvenu toleranciju prema nasilju, procjenu znanja o fenomenu, njegovoj prepoznatljivosti, percepciju nasilja nad ženama kao privatnom ili javnom problemu, a prije svega na povezanost između tradicionalnih vrijednosti (koje se odnose na percepciju ženskih i muških rodnih uloga i položaja žena i muškaraca u društvu) i tolerancije prema nasilju. Analiza pokazuje trend smanjenja osjetljivosti na nasilje i rastući trend tolerancije prema nasilju nad ženama te dodjeljivanje krivnje žrtvama, kao i porast percepcije nasilja u obitelji kao privatnoga, a ne javnog pitanja.
\end{abstract}

Ključne riječi: nasilje nad ženama, privatna sfera, javno mnijenje, Slovenija 